\title{
MÁQUINA CURUPIRÁ: DISPOSITIVOS DE UM CORPO EM CRIAÇÃO NA FRONTEIRA ENTRE O XAMANISMO AMAZÔNICO E O TEATRO
}

\author{
Me. Andréa Bentes Flores \\ UFMG/UFPA
}

\begin{abstract}
Resumo
Tenho denominado de Máquina Curupirá o processo criativo que desenvolvo como pesquisa poética acerca das comicidades indígenas da Amazônia, que tem a imagem do lendário Curupira com os pés virados para trás como atitude poética e política de um corpo que se quer deformado, fora da forma, do comportamento e do pensamento colonizado. Neste artigo, cartografo três intensidades do acontecimento cênico em processo, a saber, a multiplicidade do corpo por economia da alteridade; a adoção da atitude de atriz-xamã; e a negação do acontecimento como espetáculo, aproximando-o da noção de Máquina. Em cada intensidade, atravesso a criação pelo meio, reconhecendo os dispositivos com os quais opero, em cena, o transver, o riso entre indígenas amazônicos em ficções e fabulações contaminadas de trapaças, malinagens e epistemologias xamânicas da floresta profunda, que questionam o caminhar com os pés virados para frente.
\end{abstract}

\section{Palavras-chave:}

Comicidade indígena; Epistemologias da floresta; Xamanismo; Processo criativo.

As portas se abrem, para que as testemunhas entrem. Eu as convidei. São poucas, aproximadamente três ou quatro, que se acomodam nos cantos da sala. A sala fica em qualquer lugar. Até aqui, não há um lugar definido para o acontecimento que surge com meu corpo, ao longo dos laboratórios de criação que eu tenho desenvolvido. Nesses laboratórios, espaços abertos a experiências de criação, por vezes estou só, noutras partilho o momento com parentes que se agregam a esta pesquisa. E vou descobrindo, em processo, espaços, corpos, textualidades, xamanizações possíveis para esta pesquisa-cena.

\section{Abstract}

I have named as Curupirá Machine the creative process that I develop as poetic research about indigenous comicalities from the Amazon, which has the image of the legendary Curupira with his feet facing back as poetic and political attitude of a body that recognizes itself as deformed, out of colonized shape, behavior and thought. In this article, I map three intensities of the scenic happening in process: the multiplicity of the body by economy of otherness; the adoption of the attitude of actress-shaman; and the denial of the happening as a spectacle, bringing it closer to the notion of Machine. On each intensity, I cross the creation from the middle of it, recognizing the devices with which I run, on the scene, the act of transverthelaughteramong Amazonianindigenous into fictions and fabulations contaminated with cheating, tricks and shamanistic epistemologies of the deep forest, that question the walking with the feet facing forward.

\section{Keywords:}

Indigenous Comicalities. Epistemologies of the forest. Shamanism. Creative Process.

O que abro ao público, ao leitor, é um espaço de trabalho, de processo criativo, que é, em si mesmo, uma cartografia poética. Ela atravessa pelo meio, sempre pelo meio, um acontecimento cênico em processo, Curupirá, poética cênica que é minha pesquisa de doutoramento em Artes. Convido o leitor, que aqui será tratado como testemunha, a entrar, por alguns instantes, em uma breve cartografia de meu processo de criação e pesquisa. Para que compreendam o que acontece aqui, nesta pesquisa cartográfica tenho traçado um mapa poético de comicidade indígena amazônida, no qual transvejo, em cena, o riso que emana de 
dentro da floresta. Transver, aqui, aprendido na poesia de Manoel de Barros (1996) como ato do olho do artista, que vai além de ver e rever; mais do que isso, para o poeta, o mundo pede para ser transvisto. Minha poética tem essa qualidade de olhar, que cria sem almejar reproduzir o mesmo, mas que poetiza a experiência em fabulações, ficções, invenções.

O riso para o qual olho, transvendo, está presente no cotidiano, nos mitos e ritos de diversas nações indígenas locais. Sigo pistas deixadas por relatos de outros pesquisadores que circulam pela região, bem como nascidas em minhas próprias experiências, seja através do contato presencial entre ameríndios, seja entre saberes e práticas xamânicas amazônicas que experiencio. Esse é um riso epistêmico, já que em sua operação convoca objetos de conhecimento de si mesmo e do mundo, próprios do pensamento que emana da floresta, de maneira que as epistemologias da floresta convocam, aqui, singularidades de pensamento e criação. O convite é para que vocês compartilhem comigo algumas intensidades em maquinação no processo criativo, que tento mapear diante de vocês, aqui, em breve abertura de minha sala de trabalho.

Não há sequência lógica, cenas prontas, começo ou fim. Estamos no meio de algo, a atrizpesquisadora, seus parentes e vocês. O que tenho são pistas a serem agregadas ao mapa em algum ponto da geografia poética que percorro ao traçá-lo e, por isso mesmo, assumo seu estado inconcluso, em processo, não linear. Ensaio uma performatividade na escrita que tem meu diário de bordo do processo como uma das linhas possíveis, mas que vai além dele, em um pensamento-ação sobre a experiência vivida até aqui.

Divido estes acontecimentos em três intensidades, que assim escolhi, para seguir esta cartografia dentro de cartografia. São como três dispositivos comunicantes que uso para produzir o ato de transver. Mais adiante retomo a ideia de dispositivo sobre a qual me refiro aqui. Os três dispositivos, três intensidades, são organizadas aqui como três dias diferentes de trabalho, que esbarram um no outro e com isso também embaralho a temporalidade deste momento que vocês testemunham, dando liberdade a quem quiser ficar apenas por um dia, dois ou quem sabe participar de tudo. Também é possível achegar-se no segundo dia e somente depois experimentar o primeiro e então seguir para o terceiro, ou desistir por aí mesmo... Aventure-se no tempo, testemunha, e faça seu próprio itinerário de atenção no texto deste artigo. Eu finalizo esta escrita sem terminála, com uma imagem solitária. É uma espécie de síntese do pensamento desenvolvido aqui, mas também provoca outros desdobramentos, que deixo disponíveis para que o leitor desenvolva. Mas não é preciso esperar chegar ao final para isso. Se quiser, ela pode ser sua linha de partida. Obrigada por terem vindo.

\section{$1^{\circ}$ DIA: OLHOS DE ESPÍRITO OU TORNAR-SE XAMÃ}

A parente lara Sousa entrega-me o dispositivo de trabalho diário. Um pano de algodão de bordas desfiadas, com as quais posso amarrá-lo na cabeça, cobrindo o rosto. Pouco se vê com ele. As luzes se apagam, restando apenas a que ilumina o corredor da casa, fora da sala, tornando a visão ainda mais restrita. Estou, de certa forma, adaptada a ele, embora cada experiência seja única, especialmente agora que tenho público com quem compartilhar. Eu o recebo em meu rosto e repouso a costa sobre o pequeno colchonete no chão, onde caibo com as pernas flexionadas e mal tenho espaço para os braços. Devo ficar naquele espaço e, no tempo máximo de uma hora, passar da posição deitada para a de pés, com o máximo de lentidão possível. O trabalho começa. O tempo escorre.

sinto que morri. olhos de fantasma que larguei ali, naquele pedaço de cosmos, dentro daquele dispositivo de xamanização, de transformação do olhar. o lugar em que fui posta era como uma pequena maloca, não era fácil mover-se naquele espaço, espaço alterado, noções remexidas, onde estou? mas é menos o espaço e tanto mais o tempo que se desfaz, que se comprime. enquanto o dispositivo está em meu rosto, o tempo é curto. fora, ao retirá-lo, descubro que muito se passou e eu não pude perceber a duração dos acontecimentos. naquela experiência, movome noutro lugar, o colchonete e seus contornos é maloca-de-esmagamento-do-corpo, onde o tempo é de alguns minutos, enquanto lá fora uma hora decorre sem que eu tenha nenhuma percepção disso. onde estive, afinal?

Os xapiri são as imagens dos ancestrais animais yarori que se transformaram no primeiro tempo. 
É esse o seu verdadeiro nome. Vocês os chamam 'espíritos' mas são outros. Vieram à existência quando a floresta ainda era jovem. Os nossos antigos xamãs os faziam dançar desde sempre e, como eles, nós continuamos até hoje. [...]. Para vêlos de verdade, é preciso beber o pó de yãkoana durante muito tempo e que os nossos xamãs mais velhos abram os caminhos deles ate nós. Isso leva muito tempo. Tanto quanto os filhos de vocês levam para aprender os desenhos de suas palavras. É muito difícil. Contudo, quando faço dançar meus xapiri, às vezes os brancos me dizem: "Não se vê nada! Só se vê você cantando sozinho! Onde é que estão seus espíritos?". São palavras de ignorantes. O pó da árvore yãkoana hi não fez morrer seus olhos, como o dos xamãs. Então, por não poderem ver os xapiri, seu pensamento permanece fechado. Assim é. Os xapiri só dão a ouvir suas vozes se seu pai, o xamã, morrer com a yãkoana. Quando têm fome eles a bebem através dele. Só então podem descer sobre seus espelhos. Eles também morrem com a yãkoana, como seu pai, e assim começam a dançar e cantar para ele. Sem isso, não poderiam ser vistos. [...]Aqueles de nós que não são xamãs, do mesmo modo que os brancos, não percebem nada disso. Os espíritos são invisíveis para seus olhos de fantasma e eles só vêem os animais de caça de que se alimentam. Apenas os xamãs são capazes de contemplar os xapiri, pois, tornados outros com a yãkoana, podem também vê-los com olhos de espíritos (KOPENAWA; ALBERTI, 2015, p.111-112; 118).

morrer na maloca-de-esmagamento-docorpo foi a mais difícil das experiências. cada milímetro de ação, de vida que se manifesta ali, é dificultoso e leva tempo para acontecer, outro tempo. o processo é todo físico, de uma corporalidade que é tudo ao mesmo tempo: ossos, músculo, órgãos, ausência de órgãos, sangue, pensamento, claustrofobia, espiritualidade, dança... de repente tudo isso se amálgama na experiência e eu já não estou ali, não no mesmo lugar de sempre. os olhos já não são os mesmos, eu me debato, sinto a respiração

rarear, o coração acelera (tenho coração?), eu grito para dentro de mim: "volte!". e então preciso levantar, quebrar a maloca, remover o dispositivo dos olhos. levanto, debato, tento respirar e recobro a visão. voltei. de algum lugar, de algum tempo, choro, recebo abraço, água, voz. tenho asma. sintoquemorri. morreram meus olhos. eu morri e uma porta se abre para ver

OUTROS, xapiri, imagens de animais.

O que era aquilo? Não sou capaz de responder àquelas perguntas logo após a experiência no colchonete-maloca. Recebo abraço, água e olhos no olhos de lara. Minha percepção está alterada. Sinto todo o corpo e algo que também é corpo, mas que, ao mesmo tempo, vai além dele. Muito tempo decorre até que eu consiga (des)organizar algo para compreender o que houve ali. Lembro que certa vez, em uma experiência com Ayahuasca, a planta professora me disse, enquanto eu tentava decifrar cada espiral colorido que surgia diante de meus olhos, logo após ingerir o chá: "Tem coisa que não se entende, se vive". Foi quando meu corpo revolveu-se e então vieram mirações que sigo sem entender por completo, mas que têm forte energia de vida sobre mim.

O pano no rosto passo a denominar de Dispositivo de Xamanização. Ele age diretamente sobre meu olhar, transformando-o. Algo semelhante a uma máscara. lara lhe atribui outro nome e sua pesquisa segue em experimentação com o dispositivo junto a outros artistas; ele vai além do que posso discorrer a respeito, nem é minha intenção. $O$ fato é que a experiência gerada por ele, embora incompreensível, é vívida para este processo: sinto que, através dele, conecto-me com uma experiência singular, algo que vou chamar de estado de xamã, de pajé. O xamã está em minha pesquisa desde o início e, até aqui, evitei adjetivar-me dele, em respeito a sua importância cultural. O mergulho na criação, porém, tem me revelado outras dobras e o xamã adquire densidade conceitual no corpo da atriz em processo de criação.

Até aqui, compreendo que a comicidade entre os ameríndioséproduzidaem meio à sua compreensão e forma de viver no mundo. Nenhuma novidade nesta compreensão do riso como ato cultural. Ocorre que o xamanismo amazônico apresenta-se como epistemologia, entre cosmopolíticas marcadas pela multiplicidade perspectiva intrínseca ao real (VIVEIROS DE CASTRO, 2015). O mundo dentro da floresta é povoado de seres diversos, bichos, espíritos, artefatos, que têm papel ativo não somente na origem do mundo, como também no tipo de mundo de que se está falando. Dito de outra forma, o mundo visto pelas onças, como potencialmente por qualquer outro animal, vegetal, ou mesmo objeto, não é o mesmo visto por nós, que sequer somos os únicos que se veem como humanos, na floresta. E o riso presente nos mitos, nos ritos e no cotidiano das nações indígenas amazônicas é atravessado por 
todos esses seres, como um riso xamânico, por assim dizer.

É por esse motivo que, em sala de trabalho, procuro pelas imagens dos ancestrais animais, procuro por um corpo que os faz dançar e cantar. São eles quem contam histórias, eles quem provocam o riso. Mais adiante, aprofundo mais esse aspecto do processo de criação. Interessa, aqui, para dizer da experiência vivida com o dispositivo de xamanização em meu rosto, que a busca não é por fazer imitações precisas de animais ou quaisquer outros seres, mas de acessar imagens, estados corporais que os remetem. Aprendo com Davi Kopenawa que isto só é possível, que meus olhos só podem vê-los, meu corpo só pode fazêlos dançar, após tornar-me xamã, após perder meus olhos de fantasma. Num trabalho contínuo, naquela sala, adquiro ou almejo adquirir olhos de espíritos, olhos que podem ver as imagens dos animais ancestrais e não animais que eu conheço com meu pensamento de branco.

Escolho dizer que o pano sobre meu rosto faz-me virar xamã, a semelhança do pó de yãkoana. o pó, como outras medicinas da floresta, é uma espécie de condutor, de intermediário para as experiências xamânicas que propiciam o contato com outros mundos existentes na cosmologia ameríndia. Eu o compreendo em zonas de vizinhança com outras medicinas que conheço e faço uso, como a já citada ayahuasca, enquanto elemento disparador do devir, do acontecimento, do ato de ver e fazer dançar os xapiri, e mesmo tornar-se espírito como eles. Tornar-se espírito como os xapiri é o processo yanomami de tornar-se xamã, tornar-se pajé.

O xamã é uma multiplicidade intensiva. Não se trata de um super indivíduo, como um sacerdote, mas de alguém super dividido, povoado, atravessado e mesmo devorado por muitos entes. Como explica Viveiros de Castro (2006), sua natureza é a mesma dos espíritos auxiliares que traz à terra, de maneira que se tornar xamã é se tornar espírito, alguém diferente. Essa diferença é menos de natureza, que de grau, ou seja, negando novamente a ideia de um super ser, o xamã é alguém que adquiriu grande qualidade, capacidade adjetiva, para exercer essa função de tornar-se espírito e atuar também como uma espécie de "pai dos espíritos". Enquanto qualidade, nesse sentido, ser xamã é um atributo disponível a todos, inclusive a espécies não humanas, que, de acordo com o entendimento de diversas culturas indígenas na Amazônia, também têm seus xamãs. "Então todo indivíduo capaz de sonhar é xamã", afirma Viveiros de Castro (2006, p.322).

Naquela sala, sobre o colchonete, a plateia me vê em estado de sonho, ampliando minha qualidade de tornar-me espírito. Sou atriz-xamã, em processo sempre contínuo de tornar-me diferente. Não tenho necessidade de nomear-me de outra forma. Sinto-me conectada, como atriz, à energia dos pajés amazônicos. As testemunhas na sala de ensaio podem levantar-se. O dia de trabalho se encerra, pelo meio. Agradeço a presença de todos e convido para retornarem no próximo dia. Eles notam algo nos olhos da atriz, uma presença estranha, ou outro estado. "Quem são esses que vemos através dela?", eles se perguntam, deixando a sala intrigados.

\section{$2^{\circ}$ DIA: CORPO EM MULTIPLICIDADE POR ECONOMIA DA ALTERIDADE OU ATRIZ ONCIFICADA}

Você chega à sala e percebe que o trabalho já começou. O corpo da atriz tem muito suor. Há silêncio. Em sua vida, até aqui atuando como palhaça, aquela atriz havia experimentado outros estados cômicos. Seus ridículos, suas bobagens, se produziram sob o nariz vermelho, riso aprendido principalmente com mestres europeus, tradição ocidental. E mesmo nos momentos mais loucos e grotescos de seu corpo clownesco, ainda não havia questionado as bases de seu mundo, de seu riso, do mundo que se produzia junto com ele. Agora, anda acompanhada de vozes trapaceiras, monstruosas, comilonas, libidinosas, assustadoras, habitantes de uma floresta que sempre esteve ao seu lado, mas onde nunca havia entrado. Mata adentro, sente o corpo alargar e povoar-se de seres que alteram seus contornos, suas bordas, suas fronteiras humanas. Humana? Mata adentro é preciso perguntar-se de que humanidade se está falando.

Fiquei com a vontade... Vontade dôida de virar onça, eu, eu, onça grande. Sair de onça, no escurinho da madrugada... Tava urrando calado dentro de em mim... Eu tava com as unhas... Tinha soroca sem dono, de jaguaretê-pinima que eu matei; saí pra lá. Cheiro dela inda tava forte. Deitei no chão. [...] Quando melhorei, tava de pé e mão no chão, danado pra querer caminha. Ô sossego bom! Eu tava ali, dono de tudo, sozinho alegre, bom mesmo, todo o mundo carecia de mim... Eu tinha medo de nada! (ROSA, 2015, p.180) 
No conto de Guimarães Rosa, Meu tio o lauaretê, o ex-caçador de onça conta ao visitante sua transformação em onça, momento de alteração e desalienação metafísica, como descreve Eduardo Viveiros de Castro (VIVEIROS DE CASTRO; BELAUNDE, 2008). O conto é considerado pelo antropólogo como um dos pontos culminantes da literatura brasileira, e um espantoso exercício a respeito do pensamento indígena. o "personagem"- entre aspas porque o próprio Viveiros de Castro considera que o complexo enunciador do conto não se encaixa nessa categoria de personagem, seja ela qual for - é um mestiço, filho de uma índia com um branco, mas também sobrinho em linhagem direta de uma onça, o que o coloca em mestiçagem com a onça desde o nascimento. Aqui, ocorre, dessa forma, tanto o devir onça do mestiço, onceiro onçado, quanto o devir índio de um mestiço, duplo movimento de alteração divergente, a que Viveiros de Castro chama de diferOnça.

$\mathrm{Na}$ mitologia branca ocidental, explica o antropólogo (VIVEIROS DE CASTRO, 2015; VIVEIROS DE CASTRO et al, 2008), nosso fundo comum de existência é o fato de sermos animais, sendo algumas espécies mais animais que outras e, obviamente, a espécie humana a que mais se distancia dessa condição primitiva, reinando sobre as outras. O que ocorre na mitologia indígena amazônica é o contrário. Todo mundo é humano ou possui um fundo de humanidade comum, embora haja os que sejam menos humanos que outros. Ainda assim, todos são humanos em sua origem ou mantêm relações com humanos.

Mais do que ter uma origem humana ou manter relações de diversas formas, todo ser existente, por vezes mesmo objetos, veem a si mesmos e a seus mundos com uma perspectiva humana própria. Há, assim, entre os viventes do mundo ameríndio, uma economia da alteridade, em que a condição do outro, dualismo que separa humano e não humano, parente e inimigo, essa alteridade radical imaginada e alardeada pelo pensamento ocidental, aparece borrada, insuficiente para as relações e o modo como o mundo ameríndio se organiza, na Amazônia.

Eu diria que estamos sujeitos ao movimento de alteração divergente, do humano ao bicho, do bicho ao humano, num devir interminável. "Mecê ta ouvindo, nhem? Tá aperceiando... Eu sou onça, não falei?! Axi. Não falei - eu viro onça? Onça grande, tubixaba. Ói unha minha: mecê olha unhão preto, unha dura... Cê vem, me cheira: tenho catinga de onça?". A afirmativa do onceiro onçado de Guimarães Rosa (2015, p.188) não somente é possível, nesse contexto, como amplia minhas possibilidades de existência poética em sala de trabalho. "As onças são gente porque, ao mesmo tempo, a oncidade é uma potencialidade das gentes, em particular da gente humana" (VIVEIROS DE CASTRO et al, 2008, p.38).

Em meu trabalho, onçar, verbo criado pelo enunciador do conto de Guimarães Rosa, lançame em devires animais como potência de gente, de várias camadas ou dobras de humanidade possíveis, na operação do riso ameríndio na floresta. Meu corpo entra em multiplicidade por economia da alteridade; dito de outra forma, sou legião, sou vários, os outros são potências do corpo que eu reconheço como humano, em minha perspectiva. Em sala de trabalho, as testemunhas acompanham a diferOnça no corpo e no pensamento da atriz, alterando seu riso. 0 riso é operado, produzido, na perspectiva desses seres diferOntes, não a imitação de animais, mas devires, humanidades do universo ameríndio, imagens dos animais ancestrais, xapiri talvez. Riso que surge do devir-onça de uma atriz, jaguaridade potencial da atriz, aqui utilizando noutro contexto a expressão de Ana Carolina Cernicchiaro (2014) ao analisar os devires presentes em "Meu Tio o lauaretê", como forma ideal de uma espécie de predação do outro e de seu ponto de vista.

o que ocorre comigo em cena, em sala de trabalho, em vida, em processo de xamanização, são, assim, processos intensivos de criação/ transformação. Uso esta expressão no sentido que tem para a ideia e experiência de mundo dos Pirahã, etnia indígena localizada no Amazonas. Para essa nação, o corpo, ibiisi, é um conceito não vinculado à materialidade em si, mas à capacidade de produzir outras singularidades, que são outros corpos deformados ou imperfeitos, os quais, por sua vez, dão origem a outros seres singulares, a povoar o patamar de mundo em que vivem os Pirahã e todos os vários outros patamares existentes nessa cosmologia.

"Nesse sentido, transformação é reprodução social, metamorfose, contágio, contato, reação, predação, 
tornar-se, ser. Portanto, a transformação é o aspecto criativo da ação, aquilo que dá sentido à vida social", como explica Marco Antonio Gonçalves (2001, p.30-31), em sua etnografia dos Pirahã.

Digo, assim, que a transformação operada por metamorfose, contágio, reação, é o que dá sentido à poética xamânica que vocês testemunham aqui. Eterno tornar-se, ser é devir, um corpo em multiplicidade, que existe menos por materialidade do que por sua capacidade de produzir singularidades, outros corpos, por vezes deformados, e que podem, ainda, originar a outros seres singulares, a povoar a cena de bichos-quenunca-chegam-a-ser-coisa-alguma.

Sinto uma vontade doida de virar onça, jaguarizar pela cena. A criatura que surge lentamente diante dos olhos do público não parece humana como você. Ela tem um instrumento sonoro amarrado à boca. O som preenche a sala e seu corpo. A diferOnça se instala ali.

o apito leva-me ao cocar. o cocar eu trouxe do Acre, custou-me caro, como qualquer artefato indígena no mundo. aprendemos a explorar esses produtos como exóticos. eu trouxe o cocar sem saber ao certo o que ele é, além de um cocar. não desejo o cocar. desejo sua potência. eu brinco com ele. percorro a sala deixando-o passear pelo corpo. ele é largo e delicado, preciso ter cuidado com suas penas. tenho a sensação de que estou sempre na iminência de destruí-las. procuro a delicadeza nos movimentos, sinto peso das penas uma a uma, e depois deixo-as pousar sobre meus braços, unidas pelo fio que as ata em cocar. deixo que pousem em meus ombros, segurando a ponta do fio entre os dedos. são como asas. o corpo quer voar. eu voo, sentindo as penas pesarem nos braços. abre-me o peito. deixo o cocar arrastar-se pelas costas, pesar em minha pele. eu tomo cuidado com as penas. ele alcança meus quadris, fico de cócoras para receber aquele enrolar-se do cocar em minha cintura pélvica. tenho a sensação de que há algo ali. com as pontas presas na roupa, o cocar enrolado, agora quase cobra, é anexado ao corpo sem que eu o segure. está ao redor de meu ventre como uma saia. como um penacho, como rabo de ave. sinto minha potência ampliar, subo o corpo, estou ereta, projetando o quadril para trás. as penas deslocam meu centro de gravidade. aquele objeto ao redor de minha cintura é parte de mim e eu já sou outra. sou-sem-jamais- chegar-a-ser-ave, sou-sem-jamais-chegar-a-ser pássaro. caminho com rabo de ave. tenho uma história para contar, que só existe em meu olho de algo-que-não-chega-a-ser-pássaro.

Ao dar lugar em meu corpo a essa outra potência humana, coloco para dançar esse algo-quenão-chega-a-ser-ave, viro espírito com ele, que tem algo a dizer, algo a transmitir, o riso, através da atriz-xamã. Esse ser passa a narrar um mito e a história surge junto com o corpo e sigo experimentando a maneira desse bicho narrá-la, já que ela só existe na perspectiva dele.

Todas as coisas presentes na narrativa só existem porque assim o veem esse-que-não-chegaa-ser-pássaro. Além de ver a si mesmo como humano, esse ser habita um mundo organizado, experienciado e existente apenas em sua própria perspectiva. Não há como ter certeza se poderíamos definir o que ele chama de "sapo", por exemplo, como o animal sapo que identificamos em nosso mundo, em nossa perspectiva humana, certamente diferente da dele. As transformações, a multiplicidade do corpo transfigura o mundo daquele que vê, afirma Cernicchiaro (2014).

Penso que, ao tornar-me legião e partilhar outras perspectivas humanas em meu corpo, em diferOnça, o duplo movimento de alteração divergente também questiona quem é, ou quem são, esta atriz diante de seus olhos. Devir bicho é, também, compreender que o bicho que sou devém humana. Esse-que-nãochega-a-ser-pássaro torna-se a atriz, tanto quanto ela o incorpora, mas penso que os devires não cessam por aí. Os entes envolvidos nesse processo não são somente a atriz, o bicho e os personagens da história. Tudo acontece diante dos olhos de quem adentra minha sala de trabalho e a multiplicidade segue provocando devires também em você, testemunha. Já se perguntou como pode ver a todas estas coisas e sair ileso? Quem são você, ou quantos você se torna, por contágio, nesta experiência?

\section{$3^{\circ}$ DIA: O ESPETÁCULO-MÁQUINA}

Sala aberta. Sempre que vocês entram aqui, testemunham acontecimentos em ocorrência no corpo da atriz em processo de criação na fronteira entre o Xamanismo Amazônico e o Teatro. Como um xamã, experimento a morte de meus olhos de fantasma, para ver imagens de animais ancestrais e dar-Ihes lugar no corpo. Torno-me bicho, deixo que 
o bicho revele sua humanidade, opero diferOnça. Mesmo que não compreenda muito bem estas coisas, você é capaz de notar que atravesso um outro campo epistemológico, de floresta, que esse campo altera meu corpo e minha escrita. E, é claro, as experiências que vivemos nesta sala ultrapassam o que faço aqui, transbordam pela vida. Talvez o que você testemunhe tenha outro nome, que não espetáculo. Talvez seja algo anterior ao espetáculo, algo menor e, por isso mesmo, capaz de revolver tanto o peito da atriz e mesmo o seu.

Você não sai ileso desta sala. O perspectivismo ameríndio explica que só é possível reconhecer como humanos os da mesma espécie. Por esse motivo é que, ao nos olharmos, eu vejo que você é gente como eu. $\mathrm{E}$ ambos sabemos descrever o que é onça, quando olhamos para ela. Mas esse ser a quem vemos como onça não somente vê a si mesma como humana, como a todos de sua espécie. E eles, ao nos olharem, veem outra coisa, porcos do mato, por exemplo. Se alguém começa a ver seus iguais, outros seres humanos, como não humanos, significa que está perdendo sua perspectiva humana. Se alguém que até então você reconhecia como gente igual a você, de repente parece pássaro, onça, sua perspectiva de mundo está mudando, como se você já não fosse mais humano como o outro, está adquirindo outra natureza. Dito de outra forma, ver outros seres humanos como não humanos significa estar "virando outro". Isso acontece em dois casos, na floresta: morte ou doença. Para evitar a morte, é preciso um tratamento xamanístico (VIVEIROS DE CASTRO, 2015; VIVEIROS DE CASTRO et al, 2008).

Digo que sempre que as testemunhas veem a atriz como outra coisa que não gente como elas, como algo-que-não-chega-a-ser-pássaro, por exemplo, entram em estado de perda de sua perspectiva humana. Como uma doença, como a eminência da morte, ao adentrarem minha sala de trabalho vocês também se situam no entre do xamanismo e do teatro: não somente a atriz atravessa processos de transformação, como também todos são alterados, adoecidos, tornados outros. Por um momento, enquanto durar nossa experiência, as perspectivas humanas são remexidas e as testemunhas são convidadas a experimentarem outras existências em si mesmas, a cada vez que elas alteram o corpo da atrizxamã. Como uma grande trapaça, uma travessura que prego em todos vocês, se forem capazes de ver as transformações por que passo, é porque também já não são o que eram antes de testemunhar tudo isto. Estão, também em multiplicidade.

Isto é algo que invento para este trabalho, apropriando-me do que aprendo sobre o riso da floresta e as epistemologias com que opera. Sigo a proposta de Viveiros de Castro (2015) e faço experimentações com o pensamento indígena, não como quem o interpreta, ou tenta reproduzir um certo modo de pensar dos povos locais, mas na tentativa de tomá-lo como conceitos, como uma experiência de pensamento para esta pesquisacriação. Eu busco, assim, compreender esses conceitos como potencialmente capazes de uso artístico, poético, também a procura de vetores que apontam para o outro lado, o lá como cá, outras ideias que ocupam, aqui, o mesmo plano das ideias que teimamos a aceitar como mais razoáveis, verdadeiras.

Trata-se, como disse, de uma experiência de pensamento, que acompanha e imbrica-se à experiência poética, tornando impossível a cisão entre agir, criar e pensar. $E$ talvez seja por isso que resolva fazer travessura com as testemunhas. Penso que precisamos urgentemente adoecer um pouco, arriscar fazer morrer essa perspectiva humana de mundo que cultivamos, aqui, vivendo na cidade, afastados do pensamento da floresta. Afastados de Curupira, que caminha com os pés virados para trás, como poetiza Jones Göettert (2006), ao contrário dos que insistem em caminhar sempre para frente, caminhos retos, ordeiros, seringalistas, brancos, ocidentais, colonizadores, colonizados.

sempre percebo a sala cheia de cobras. dentre os objetos ao meu redor, tenho uma cobra de madeira, ela foi a primeira a instalar-se em meu corpo e tornar-se ente que narra histórias. a cobra repousa sobre minha coluna e obriga meu corpo vertical a rebaixar-se para recebê-la. desde que se instalou em minha coluna, mesmo depois que a retiro, parece convocar outras presenças. em cada ente que descubro no corpo, o-que-não-chega-a-serave, o-que-não-chega-a-ser-ariranha, o-quenão-chega-a-ser-onça, o-que-não-chega-aser-sapo, etc., em todos eles eu acabo percebendo a cobra pelo meio. não a cobra como ente narrador, a se repetir em todos, mas a cobra como agente de diferença, atravessando esse corpo cômico de diversas formas, por diversos caminhos, gerando transformações. em cena, acredito cada vez mais 
que sou levada a ver o mundo como cobra. minha maloca está cheia de cobras e eu desejo que elas povoem também quem estiver por perto, alterando pensamentos, risos, mundos.

A Amazônia indígena está povoada de cobras. Nãodigo isso no sentido da presença do animal, tão marcante no ecossistema local e tão ameaçado pelo violento processo de "desenvolvimento" e urbanização por que passa a região, afetando diretamente populações tradicionais e a biodiversidade. Matam muita gente e muita cobra por aqui, em todos os sentidos. Refirome à cobra como imagem recorrente, sob diferentes formas, em relatos míticos de culturas indígenas amazônidas, a quem também tentam matar, já que tanto o modo dos indígenas viverem, como também seus objetos de pensamento, juntamente com os mundos constituídos por eles, parecem incompatíveis com o avanço do capital na região e no mundo.

Marilina Conceição Pinto (2012) reuniu em sua pesquisa uma série de mitos indígenas amazônicos, registrados por outros pesquisadores, em que a cobra é mencionada e tem papel ativo, seja transformandose em barco, estrela, dentre outros, seja gerando acidentes geográficos ou filhos híbridos com mulheres humanas, e mesmo ensinando agricultura, tecelagem e cerâmica. A própria pesquisadora a identifica como instauradora de diferenças, em sua análise de mitos onde é a cobra a responsável pelo cromatismo dos pássaros e pelas cores do arco-íris, embora o tipo de análise e o pensamento que orienta a pesquisadora em seu processo sejam diferentes do que ocorre nesta pesquisa. Interessa-me, aqui, em especial, um relato agregado a sua pesquisa a respeito de um possível destino da Cobra Unurato, um dos filhos híbridos que a cobra-grande deixou no mundo, conforme narrativa Arapaço, grupo indígena situado no Amazonas. Após levar um tiro acidental de um branco que tentava ajudá-lo a sair do encanto de ser cobra de dia e gente de noite, Unurato teria se tornado sempre humano; mas em outras versões do mesmo mito, conta a pesquisadora:

Unurato volta para seu povo na forma de um submarino carregado de mercadorias. Aparece à meia-noite, o navio tem luz elétrica. Com as máquinas, os seres-cobra estão construindo uma cidade imensa dentro do rio. Quando você chega lá perto, ouve o barulho dessas máquinas dentro da água (PINTO, 2012, p.62).

Penso que a poética cênica em processo nesta sala de trabalho é uma das Máquinas possíveis com que cobras podem construir algo. Algo que não tem forma definida, como a cidade dentro do rio, no mito Arapaço. Algo anterior, que não sabemos bem o que é, mas que causa barulho e podemos ouvir. Algo construído, produzido, criado, que atravessa a todos os que fazemos parte do acontecimento. Não quero dar nomes, ainda, ao que produz Curupirá, enquanto Máquina, mesmo porque acredito que, ao estabelecer definições, limito sua potência. $E$, além do mais, o que as testemunhas acompanham é apenas um processo, que sempre estará pelo meio, mas que, de fato, apenas inicia um percurso.

O que sei é que esta Máquina opera com dispositivos. A ideia de dispositivo que uso aqui está na arma com que o onceiro onçado de Guimarães Rosa passa a usar, ao deixar de matar onças com armas de fogo. Se antes ele usava aquele tipo de arma para desonçar aquela terra, agora usa uma zagaia, matando homens e entregando-os às onças. Movimento de desgentar a região. (CERNICCHIARO, 2014; ROSA, 2015). Os dispositivos que colocam a máquina em operação, em produção, são zagaias que desgentam, que deliberadamente querem matar certos tipos de modos de viver e pensar arraigados nesta terra.

Curupirá é Máquina, máquina de cobra que faz barulho e altera perspectivas. Os bichos que me povoam são como seres-cobra, operando maquinaria, criando mundos, do lado de dentro, de dentro da atriz, de dentro das testemunhas. Operando algo que tem a ver com um contra-movimento: da desoncificação, à desgentação. Da morte das cobras e gentes daqui, da morte dos modos amazônicos de ver e compreender o mundo a maquina e seus dispositivos que produzem barulho contra silenciamento, contra invisibilização. Em celebração ao modo como caminha o Curupira, com minha poética convido a curupirar, virar os pés, virar a cabeça, alterar perspectivas. Curupirar, Curupirá. Curupirá é a virada de um corpo que abandona o Ocidente como ponto de referência absoluta de pensamento e, neste caso, de criação. Máquina que quer reunir forças de riso resistente, decolonial, traiçoeiro e abusado, potente para a vida humana dentro e fora da Amazônia. É preciso Curupirá o mundo e ainda haverá um dia em que o mundo Curupirá.

Obrigada por terem vindo. 


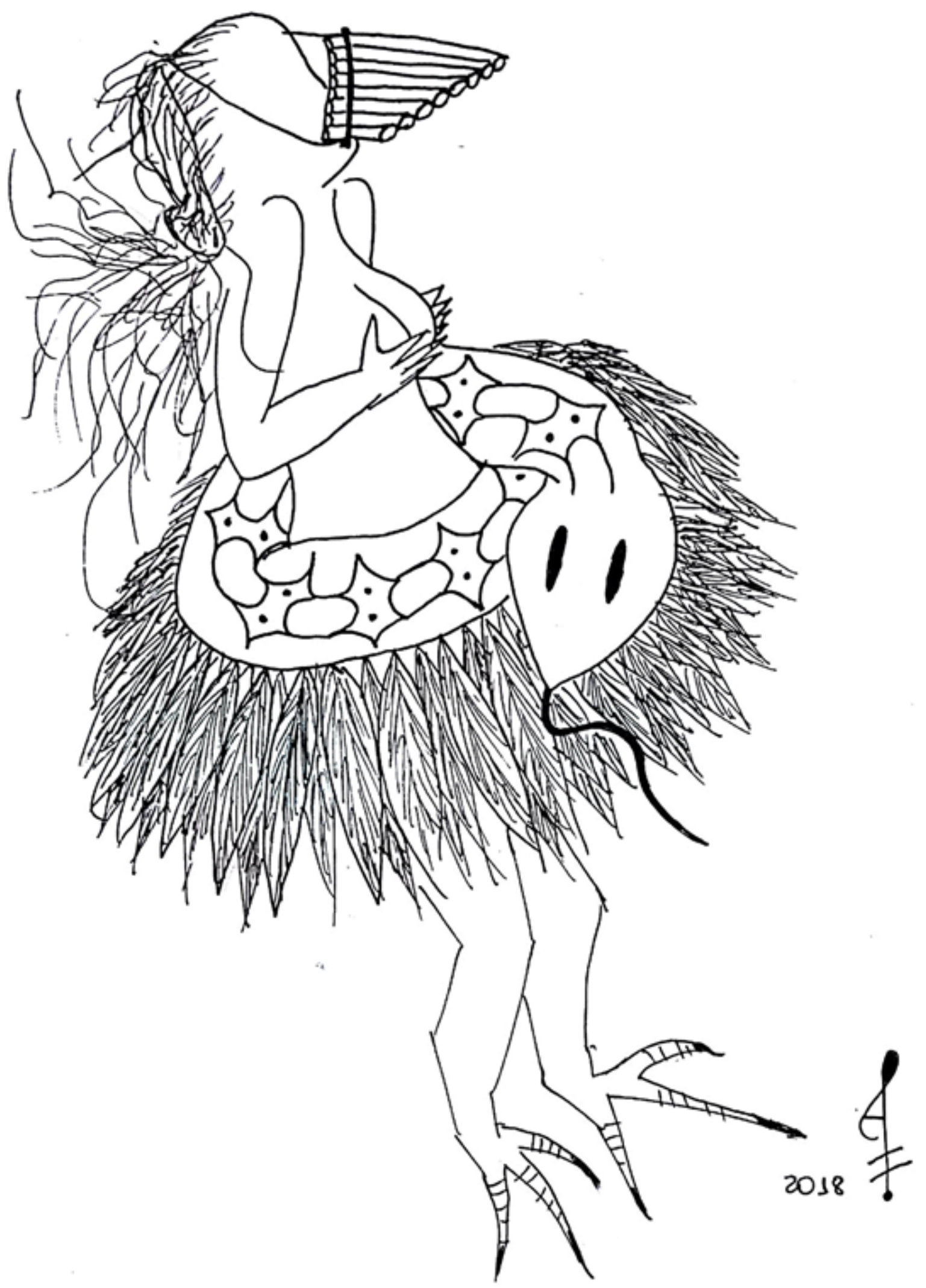

Figura 1 - Esse-que-nunca-chega-a-ser-pássaro. Fonte: Diário de Bordo de Andréa Flores (2018). 


\section{REFERÊNCIAS}

BARROS, Manoel de. Livro sobre nada. Rio de Janeiro: Record, 1996.

CERNICCHIARO, A. C. Antropofagia e perspectivismo: a diferonça canibal em "Meu Tio o lauaretê". Revista Landa, Santa Catarina, v.3, n.1, p.84-102, 2014.2. Disponível em: <http:// www.revistalanda.ufsc.br/vol-3-no-1-2014>. Acesso em: 03 jan. 2018.

GÖETTERT, J. D. Dos pés virados do Curupira. Rio Branco: EDUFAC, 2006.

GONÇALVES, M. A. 0 mundo inacabado: ação e criação em uma cosmologia amazônica. Etnografia Pirahã. Rio de Janeiro: UFRJ, 2001.

KOPENAWA, D.; ALBERTI, B. A queda do céu: palavras de um xamã yanomami. São Paulo: Cia. Das Letras, 2015.

PINTO, M. C. O. B. S. Cultura e ontologia no mito da cobra encantada. Manaus: EDUA, 2012.

ROSA, G. Meu tio o lauaretê. In: Estas

estórias. 7 ed. Rio de Janeiro: Nova Fronteira, 2015. p.155-190.

VIVEIROS DE CASTRO, E. A floresta de cristal: notas sobre a ontologia dos espíritos amazônicos. Cadernos de Campo, São Paulo, n.14/15, p.319-338, 2006. Disponível em: < http:// www.revistas.usp.br/cadernosdecampo/article/ view/50120/55708>. Acesso em: 29 dez. 2017.

Metafísicas canibais: elementos para uma antropologia pós-estrutural. São Paulo: Cosac Naify, 2015.

VIVEIROS DE CASTRO, E; BELAUNDE, L. E. "O perspectivismo é a retomada da antropofagia oswaldiana em novos termos". In: SZTUTMAN, R. (Org.). Eduardo Viveiros de Castro: encontros. Rio de Janeiro: Beco do Azougue, 2008. p. 114129.

VIVEIROS DE CASTRO et al. "O chocalho do xamã é um acelerador de partículas" 1999. In: SZTUTMAN, R. (Org.). Eduardo Viveiros de Castro: encontros. Rio de Janeiro: Beco do Azougue, 2008. p. 24-49.

\section{SOBRE A AUTORA}

Andréa Bentes Flores é Atriz, palhaça e diretora de Teatro, professora efetiva da Escola de Teatro e Dança da Universidade Federal do Pará (ETDUFPA). Doutoranda em Artes pela Universidade Federal de Minas Gerais (DINTER/EBA/UFMG). Mestre em Artes pelo Instituto de Ciências da Arte da UFPA (ICA/UFPA). Especialista em Estudos Contemporâneos do Corpo: Criação, Difusão e Recepção, vinculada ao ICA/UFPA. Graduada no Curso Técnico de Formação em Ator (ETDUFPA). Graduada em Terapia Ocupacional (UEPA). Coordenadora do projeto de extensão Animalidades Poéticas. Membro das Coletivas Xoxós (Belém,PA), atua em espetáculos solos e performances. Desenvolve pesquisas cartográficas em comicidade amazônida, fronteiras entre xamanismo amazônico e Teatro, e palhaçaria feminista. Interessa-se, ainda, pelos atravessamentos epistêmicos e poéticos entre poesia, saberes da floresta e escrita em Artes. Em cena, atualmente, com os espetáculos Rala, Palhaço!, Ovo n)13 e Curupirá. Desenvolve seu novo projeto em vias de iniciar as atividades, intitulado: "Poéticas e comicidades de re-existência nas Amazônias: comicidades afroindígenas e palhaçaria feminista". 